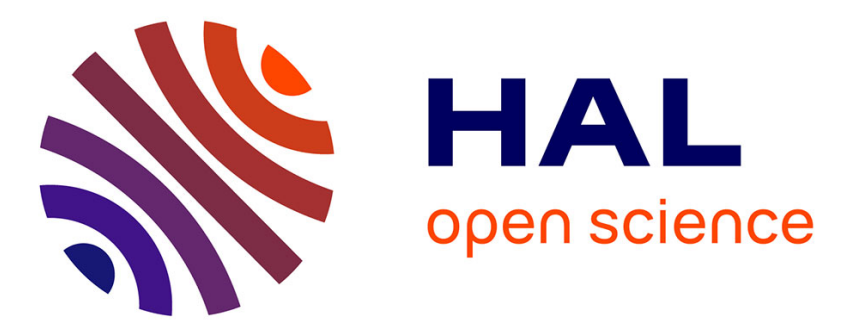

\title{
Emergence and evolution of new industries: The path-dependent dynamics of knowledge creation. An introduction to the special section
}

Jackie Krafft, Sebastien Lechevalier, Francesco Quatraro, Cornelia Storz

\section{- To cite this version:}

Jackie Krafft, Sebastien Lechevalier, Francesco Quatraro, Cornelia Storz. Emergence and evolution of new industries: The path-dependent dynamics of knowledge creation. An introduction to the special section. Research Policy, 2014, 10 (43), pp.1663-1665. 10.1016/j.respol.2014.07.006 . hal-01076410

\author{
HAL Id: hal-01076410 \\ https://hal.science/hal-01076410
}

Submitted on 17 Nov 2014

HAL is a multi-disciplinary open access archive for the deposit and dissemination of scientific research documents, whether they are published or not. The documents may come from teaching and research institutions in France or abroad, or from public or private research centers.
L'archive ouverte pluridisciplinaire HAL, est destinée au dépôt et à la diffusion de documents scientifiques de niveau recherche, publiés ou non, émanant des établissements d'enseignement et de recherche français ou étrangers, des laboratoires publics ou privés. 


\title{
Emergence and evolution of new industries: The path-dependent dynamics of knowledge creation. An introduction to the Special Section.
}

Received 1 March 2012

Accepted 25 April 2014

\author{
Jackie KRAFFT \\ University of Nice Sophia Antipolis, GREDEG-CNRS \\ 250, rue Albert Einstein \\ 06560, Valbonne (France) \\ Tel: + 33493954170 \\ E-Mail: Jackie.Krafft@gredeg.cnrs.fr \\ Sebastien LECHEVALIER \\ Ecole des Hautes Etudes en Sciences Sociales \\ 105 boulevard Raspail 75006 Paris \\ Email: sebastien.lechevalier@ehess.fr \\ Francesco QUATRARO (corresponding author) \\ University of Nice Sophia Antipolis, GREDEG-CNRS \\ 250, rue Albert Einstein \\ 06560, Valbonne (France) \\ Tel: +33 493954373 \\ Email address: Francesco.quatraro@unice.fr \\ and \\ BRICK (Bureau of Research on Innovation, Complexity and Knowledge), \\ Collegio Carlo Alberto \\ Cornelia STORZ \\ University of Frankfurt \\ Department of Economics and Business Administration \\ Grüneburgplatz 1 D-60323 Frankfurt am Main \\ Tel.: +49-69-798-34811 / -34809 \\ email: storz@wiwi.uni-frankfurt.de
}

\begin{abstract}
In this introduction, we review the arguments that underpin the rationale for the special section, and provide a structured sequence for the contents of the six selected papers that comprise the section.
\end{abstract}


Keywords: Innovation, Technological Change, Path Dependence, Economic Development, Firms, Evolutionary Economics, Regions 
The path-dependent dynamics of emergence and evolution of new industries: Introduction

Highlights

- We provide the background framework to the special section

- We present the special section illustrating the coherence of the contributions

- We provide a short description of the papers included in the section 


\section{The path-dependent dynamics of emergence and evolution of new industries: Introduction ${ }^{1}$}

The dynamics by which new industries are created, and how these develop over time, represent a crucial issue for understanding the evolutionary patterns of capitalistic economies. Change is indeed the main engine of growth (Nelson, 1990; Metcalfe et al., 2006). Such dynamics are grounded on the interplay between the phenomena of structural change, i.e. the change in the sectoral composition of an economic system, and technological change (Malerba, 2007; Quatraro, 2012). Actually, the creation of new industries alters the sectoral landscape in the economy, engendering structural changes. Very often, the creation of new industrial activities is made possible by technological progress, which provides the inputs to the design of new products. Creative destruction, enabled by innovation efforts, is a key part of the process leading to the emergence of new sectors (Schumpeter, 1942). Moreover, the change in the industrial structural structure is likely to stimulate the creative response of incumbents, which will likely undertake innovation efforts (Schumpeter, 1934). In this direction, structural change becomes both an incentive and an outcome of an endogenous process of technological change.

Considering Schumpeter (1934, 1942) but also Marshall (1920, 1925) as the founding fathers in the field, there are alternative reasons why an industry may emerge. First, the emergence of an industry may be essentially driven by technology. This calls to mind Schumpeter's vision of creative destruction in industrial dynamics. An entrepreneur sets up a firm to introduce his invention. This firm grows and holds a monopoly position for some time, but this firm is imitated by new entrants that compete with and eventually outperform the initial firm. This situation can last until another entrepreneur develops a new project involving the exit of older and larger firms and the entry of new ones (Saviotti, 1996). But we can also think about the process in a different manner. We can consider that knowledge and competencies drive the emergence the industry. In that case, closer to Marshall and the postMarshallianvision, the growth of knowledge is linked to the ability of firms to ensure

\footnotetext{
${ }^{1}$ The authors wish to thank the editor Ed Steinmuller for his guidance during the whole process leading to the publication of this special section. We thank Pablo d'Este, DietmarHarhoff, Attila Varga, Torben Schubert, Alex Coad, Brian Loasby, Martin Fransman, Guido Bünstorf, Mark Lehrer, Bill Lazonick, Stan Metcalfe, Steven Casper for their help in the process. Jackie Krafft and Francesco Quatraro acknowledge the financial support of the European Commission, within the context of the FP7 research project 'Policy Incentives for the Creation of Knowledge: Methods and Evidence' (PICK-ME), Grant number 266959. Cornelia Storzacknowledges the financial support of the German Research Foundation (DFG) for the project "Human Resource Management in New Industries", Grant number STO 860/1-1.
} 
coherence between internal economies (organization and direction of the resources of the firm) and external economies (general development of the economy, including the role of firms in the neighbourhood). From this perspective, the creation of new activities may be related to the firmsopportunity and ability to accumulate specific knowledge and competencies and generate novelty (Loasby, 1999).

Despite the richness of these early contributions, and some notable advances in recent industrial dynamics (the work by Steven Klepper has been here central here, from Gort and Klepper, 1983, to Anderson and Klepper, 2013), the understanding of this process is still limited in the field of economics of innovation. This is all the more surprising since economic development all times has been essentially nurtured by the emergence of new industries (see over the last two decades software and biotechnology, and today nanotechnology or next generation robotics).This special section of Research Policy ${ }^{2}$ aims to improving our understanding of processes of industry emergence and the role of path dependencies within this process, and hereby hopes to substantiate innovation research.

In this framework, bringing about some 'novelty' in the market is not necessarily linked to the introduction of a radically new product or process. The degree of novelty can be a relative concept, according to which a technology or a product can be new to some contexts, even though they are not new in absolute terms. Studies focusing on 'new industries', too often assume that sectors emerge from nothing. On the contrary, the analysis of the conditions underpinning the emergence of new industries needs therefore to pay attention also to the specific characteristics featuring the environmentsto which they are new, i.e. the combination of firms and institutions that make them new (Dietrich and Krafft, 2012).

The evolutionary process by which competences are accumulated over time plays such a role that the patterns of change in industrial structure are expected to be path dependent.In this special section, the concept of "path" is used in conjunction with the simple idea that "history matters", and path dependence is taken as the expression of the influence of structures inherited from history (David 1985; Arthur 1989, 1994). Initial conditions as well

\footnotetext{
${ }^{2}$ Some of the initial drafts of papers in this special section of Research Policy have been presented at a workshop co-organized by BRICK (Bureau of Research on Innovation, Complexity and Knowledge) and CNRS-GREDEG, hosted by the Collegio Carlo Alberto in Torino (Italy), with the support of Fondation France-Japon de l'EHESS. We would like to thank the participants of the workshops for their valuable comments. We are also grateful to the members of the workshopscientific committee, in particular BjörnAsheim, Cristiano Antonelli, Michel Callon, Steven Casper, DietmarHarhoff, Franco Malerba, Simone Strambach, JörgSydow, Nick Von Tunzelmann and SeiichiroYonekura.
} 
as the choices of economic agents at different moments in time are likely to shape the likelihood for some industries to emerge and their probability to survive. As an example, empirical evidence suggests that industrial diversification in local contexts is more likely to be successful when new industrial activities are to some extent related to those already in place (Frenken et al., 2007; Boschma et al., 2013), and that new industry creation shows strong cross-country differences due to different initial institutional and technological regimes (Casper et al. 2004, Storz, 2008). The appreciation of the very dynamics leading to the introduction of new industrial activities cannot therefore disregard the evolution of the techno-economic environment in which they are supposed to take root.

In this special section we analysethe initial conditions of the industry and how they affect the pattern of industry emergence. Indeed, a number of important industry sectors emerged as a result of certain radical innovations, which substantially changed the path of former sectors and their rebirth into new ones, becoming eventually sub-industries of former sectoral categories. In order to understand the processes of emergence of new industries, it is thus important to acknowledge that this process is strongly shaped by the dynamics of knowledge creation in the geographic and the technological space, the technological regimes as well as the institutional setting. Several driving forces are at stake in this framework, involving the creation of new innovative firms, for example through spinoffs, the mobility of skilled labour force enabling knowledge transfer and exploitation in new contexts, firms' diversification patterns and the establishment and evolution of network linkages.

Such variety of mechanisms will be explored in the articles contributing this special section, which is ideally structured in three parts: i) spatial factors affecting the emergence of a new industry, ii) microeconomic determinants of industry emergence and search behavior and iii) the role of institutional and technological regimes.

As far as the first part on how spatial factors affect industry emergence is concerned, the articles tackle the issue of space from a multidimensional perspective. The first paper of Mathijsde Vaan on "Interfirm networks in periods of technological turbulence" shows the interplay between the evolutionary patterns of inter-firms linkages and those of technological lifecycles. The emergence of new trajectories, and as a consequence of new products, in the videogames industry is better faced by incumbents featured by high diversity of network partners. This makes this industry deviate from traditional evidence about industry lifecycles (de Vaan, 2014). In their article on "The emergence of new technology-based sectors in 
European regions: A proximity-based analysis of nanotechnology", Alessandra Colombelli, Jackie Krafft and Francesco Quatraroshow that besides relational space, technological and geographical dimensions also matter when the emergence of new industries is at stake. The introduction of 'new' activities indeed does not occur in the air, but rather in local contexts which exhibit specialization patterns in already existing activities. These in turn rely on specific competences, which have been accumulated over time and constrain the directions that local industrial and technological diversification may undertake. Geographical and technological spaces show therefore some degree of overlap, and the emergence of new activities is more likely to occur and be successful when these are related to the competences already developed by local agents. This dynamics is all the more evident when new activities are based on brand new technologies, like nanotechnology (Colombelli et al., 2014).

In the second part on microeconomic determinants in industry emergence, Marco Guerzoni, T. Taylor Aldridge, David B. Audretsch and Sameeksha Desai examine in their paper on "A New Industry Creation and Originality: Insight from the Funding Sources of University Patents" the determinants of patents' originality, as a condition to the emergence of new technology-based industries, with particular focus on the role of university research (Guerzoni et al., 2014).Using data on patented cancer research, they analyse how the research context, in particular the funding source for each scientist, is associated with patent originality. By looking at "The emergence of the education tool industry: Opportunities and challenges for innovation in education", D. Foray and J. Raffo (2014) provideevidence of the microeconomic conditions favouring the emergence of new industries. They investigate the population of small firms that begun to invent and commercialize (mainly ICT-based) technologies related to education practices, and provide evidence of the new accumulation of competences in this new branch as well as of the difficulties in finding a viable market for these technologies, above all as far as the public education is concerned.

The third part on the role of institutional and technological regimes tackles the issue of the emergence of new industries by focusing on the historically evolving structure in which new industries emerge. SébastienLechevalier, Junichi Nishimura and Cornelia Storz investigate the role of institutional regimes and key actors in processes of industry emergence. In their paper on "Diversity in patterns of industry evolution: how an intrapreneurial regime contributed to the emergence of the service robot industry", they analyse, by using data of Japanese patent applications, the role of new firms and of collaborations in the process and industry emergence and find that the emergence of the industry is mainly triggered by 
established large firms, rather than by new firms (Lechevalier et al., 2014). The following article of Kenneth L. Simons and Susan Sandersonon "Light Emitting Diodes and the Lighting Revolution: The Emergence of a Solid-State Lighting Industry" analyses how a solid-state lighting industrygrew out of light emitting diode (LED) technologies that evolved for half a century. This paper investigates how a diversity of key actors like tens of thousands of researchers in universities, national laboratories, and firms affected the process of industry emergence (Sanderson and Simon, 2014).

This special section is intended to present and discuss some of the key issues that are rising today in the research field of the path-dependent dynamics of emergence and evolution of new industries. While the contributions contained in the special section do not exhaust the possible investigations, we think they contribute to structuring the future research agenda in the field. Avenues of research over the next year will lie in the in-depth exploration of the relations existing between spatial aspects, micro-foundations and technological/institutional regimes in the emergence of new industries. 


\section{References}

Andersson, M. and Klepper, S. 2013.Characteristics and performance of new firms and spinoffs in Sweden.Industrial and Corporate Change. 22(1), 245-280.

Arthur WB. 1989. Competing technologies, increasing returns, and lock-in by historical events. Economic Journal 99, 116.31

Arthur WB. 1994. Increasing Returns and Path Dependence in the Economy. Ann Arbor: University of Michigan Press.

Boschma, R.A., Minondo, A., Navarro, M., 2013.The emergence of new industries at the regional level in Spain.A proximity approach based on product-relatedness. Economic Geography 89, 29-51.

Casper, S. and R. Whitley, 2004.Managing competences in entrepreneurial technology firms: a comparative institutional analysis of Germany, Sweden and the UK. Research Policy33, 89-106.

Colombelli, A., Krafft, J. and Quatraro, F., 2014. The emergence of new technology-based sectors in European regions : A proximity-based analysis of nanotechnology. Research Policy, this issue.

David P., 1985. Clio and the Economics of QWERTY. American Economic Review 75, 332337.

Dietrich M. and Krafft J.(eds), 2012. The Handbook on the Economics and Theory of the Firm. Edward Elgar: Cheltenham.

deVaan, M., 2014. Interfirm networks in periods of technological turbulence and stability. Research Policy, this issue.

Foray, D. and Raffo, J., 2014.The emergence of an educational tool industry: Opportunities and challenges for innovation in education. Research Policy, this issue.

Frenken, K., von Oort, F., Verburg, T., 2007.Related Variety, Unrelated Variety and Regional Economic Growth.Regional Studies 41, 685-97.

Gort, M. and Klepper, S. 1982.Time Paths in the Diffusion of Product Innovations.Economic Journal, 92(367), 630-53.

Guerzoni, M., Aldridge, T.T., Audretsch, D.B. and Desai, S., 2014. A New Industry Creation and Originality: Insight From The Funding Sources of University Patents. Research Policy, this issue.

Lechevalier, S., Nishimura, J. and Storz, C. 2014.Diversity in patterns of industry evolution: how an intrapreneurial regime contributed to the emergence of the service robot industry in Japan.Research Policy, this issue. 
Loasby, B. 1999.Knowledge, Institutions and Evolution in Economics. London and New York: Routledge.

Malerba, F., 2007. Innovation and the dynamics and evolution of industries: Progresses and challenges. International Journal of Industrial Organisation 25, 675-699.

Marshall, A. 1920.Principles of Economics, London: Macmillan.

Marshall, A. 1925.Some aspects of competition, reprinted in AC Pigou (ed), Memorials of Alfred Marshall, London: Macmillan (originally 1890).

Metcalfe S.J, Foster J. and Ramlogan R. 2006. Adaptive Economic Growth. Cambridge Journal of Economics 30, 7-32.

Nelson, R.R., 1990. Capitalism as an engine of progress. Research Policy 19, 193-214.

Quatraro, F., 2012.The economics of structural change in knowledge. London and New York, Routledge.

Saviotti, P. 1996. Technological evolution, variety and the economy. Edward Elgar, Cheltenham.

Sanderson, S.W. and Simons, K.L., 2014.Light Emitting Diodes and the Lighting Revolution:The Emergence of a Solid-State Lighting Industry. Research Policy, this issue.

Schumpeter, J.A., 1934. Creative response in economic history.

Schumpeter, J.A., 1942. Capitalism, socialism and democracy. London, Unwin.

Storz, C., 2008. Dynamics in Innovation Systems: Evidence from Japan's Game Software Industry. Research Policy 37, 1480-1491. 